\title{
DEFATTED MAIZE GERM IN EQUINE DIETS
}

\author{
GÉRMEN DE MILHO DESENGORDURADO NA DIETA DE EQUINOS
}

\section{Camila GIUNCO²; Gabriela RIBEIRO²; Liandra Maria Abaker BERTIPAGLIA ${ }^{3}$; Mikaele Alexandre PEREIRA'; Olivia Carmen Araujo NASCIMENTO²; Roberta Ariboni BRANDI ${ }^{1}$}

1. Zootecnista, Faculdade de Engenharia de Alimentos e Zootecnia - FZEA), Universidade de São Paulo - USP, Pirassununga, SP, Brasil. robertabrandi@usp.br; 2. Faculdade de Engenharia de Alimentos e Zootecnia - FZEA, Universidade de São Paulo - USP, Pirassununga, SP, Brasil; 3. Universidade Camilo Castelo Branco - Unicastelo, Descalvado, SP, Brasil.

\begin{abstract}
This study investigated the inclusion levels of defatted maize germ (DMG) in the diet of horses by determining the apparent digestibility coefficients of the nutrients, and the physicochemical parameters of feaces and blood samples. Four adult horses, weighing $483.3 \pm 27.5 \mathrm{~kg}$ average, arranged in $4 \times 4$ Latin square were used. The energy provided by the diets came from hay, 50\% (Jiggs hay), and from the concentrate, 50\%, with increasing DMG levels (0, 10, 20 and 30\%). Digestibility was determined using samples from total feaces collection. The characteristics of color, consistency, $\mathrm{pH}$ and buffering capacity (BC) 5 and 6 of the feaces were determined daily during the collection days. The blood samples were collected by venipuncture of the jugular, with vacuum tubes, to determine the concentration of glucose, triglycerides, cholesterol and insulin using biochemical kits and the concentration of short-chain fatty acids, by gas chromatography. The diets did not affect significantly $(\mathrm{P}>0.05)$ the digestibility of nutrients, fecal $\mathrm{pH}(\mathrm{mean} 6.7)$, buffering capacity at pH 5 (22.7) and pH 6 (6.9), and fecal concentration of short-chain fatty acids. Likewise, diets did not affect significantly $(\mathrm{P}>0.05)$ the blood concentrations of glucose, insulin, cholesterol, and total short-chain fatty acids. However, diets changed significantly $(\mathrm{P}<0.05)$ the blood concentrations of triglycerides, described by the equation $\hat{y}=$ $30.62+0.26 x$. The triglycerides, glucose and insulin variables also changed significantly $(\mathrm{P}<0.05)$ over time, according to the following equations: $\hat{y}=32.30+0.87 x ; \hat{y}=85.93+3.17 x-0.61 x^{2} ;$ and $y=3.19+1.38 x-0.22 x^{2}$, respectively. The defatted maize germ can be included up to $30 \%$ of the concentrate (up to $9.6 \%$ of the diet) without changing the diet apparent digestibility coefficient, and feaces and blood physicochemical parameters. This ingredient can be an alternative for high fiber diets and can contribute to formulating diets with lower glycemic and insulinemic indexes.
\end{abstract}

KEYWORDS: Co-product. Digestibility. Horse. Metabolism. Nutrition.

\section{INTRODUCTION}

Historically, horse feed is based on corn, soybean meal, wheat bran, oats, and grains as components of the concentrate (FURTADO et al., 2011). However, new energy ingredients composed of "super fibers" are being investigated due to the current suggestion to restrict starch intake in the concentrates fed to horses (VERVUERT et al., 2009). These are co-products capable of generating energy similar to grains via fermentation (DUREN, 2000).

Ingredients with these characteristics have been studied by several researchers: citrus pulp (BRANDI et al., 2014; MOREIRA et al., 2015; MENEZES et al., 2014), soybean hulls (QUADROS et al., 2004; MANZANO et al., 1999; COVERDALE et al., 2004), and corn gluten 21 (CORREA et al., 2016). However, the literature on the feasibility of using corn co-product in the equine diet is limited. Frape (2008) states that feeds based on maize gluten are appropriate for horse feed mixtures because they are palatable and free of toxins. But, there is little information available in the literature on how to use this co-product.

The defatted maize germ (DMG) is a maize co-product, which results from the separation of germ, gluten, and starch using a wet process. After wet milling, the germ is dried and pressed to remove the oil (ANDRIGUETTO et al., 1982). The literature review reported no studies on the use of defatted maize germ in the diet of horses. However, there are studies with other species such as pigs (MOREIRA et al., 2002), fish (PEZZATO et al., 2002), and broiler chicken (BRUNELLI et al., 2006).

Corn gluten 21, which is the product that most closely resembles DMG, has been investigated by Correa et al. (2016). The authors found no effect of the ingredient on diet apparent digestibility coefficient, feaces physicochemical parameters, and blood glucose levels.

This study investigated the inclusion level of defatted maize germ in the diet of horses by determining diet apparent digestibility coefficients, as well as feaces and blood physicochemical parameters. 


\section{MATERIAL AND METHODS}

All procedures were approved by the Ethics Committee on Animal Experimentation, College of Animal Science and Food Engineering (FZEA), University of São Paulo (USP), Protocol CEP FZEA 14.1.542.74.7.

The experiment was conducted in the horse sector of the University campus in Pirassununga, SP. The four, no defined breed, adult horses weighed $483.3 \pm 27.5 \mathrm{~kg}$ and were 9.3 years old, on average, and the body score was about 5 , for a 0 to 9 body escore scale. They were housed in individual box stalls, with cement floor and $12 \mathrm{~m}^{2}$ in area, and arranged in $4 \times 4$ Latin square design.

The experimental diets were formulated according to the requirements for maintenance horses of the Nutrient Requirements Council (NRC, 2007). The diets' energy came from Jiggs hay used as roughage $(50 \%)$ and from concentrate $(50 \%)$ (Tables 1 and 2). The horses were fed $6.6 \mathrm{~kg}$ of Jiggs hay and $3.1 \mathrm{~kg}$ of concentrate on average, divided into two daily meals. The roughage was fed before the concentrate.

Table 1. Concentrate composition (\%) with increasing levels of defatted maize germ (DMG).

\begin{tabular}{lcccc}
\hline Ingredients $(\%)$ & \multicolumn{4}{c}{ DMG level (\%) } \\
\cline { 2 - 5 } & 0 & 10 & 20 & 30 \\
\hline Maize & 47.25 & 42.00 & 42.00 & 40.00 \\
Wheat meal & 30.00 & 27.10 & 17.00 & 11.10 \\
Soybean meal & 10.00 & 8.00 & 8.100 & 6.00 \\
Dried molasses & 10.00 & 10.00 & 10.00 & 10.00 \\
DMG & 0.00 & 10.00 & 20.00 & 30.00 \\
Limestone & 0.85 & 1.00 & 1.00 & 0.80 \\
Salt & 1.00 & 1.00 & 1.00 & 1.00 \\
Dicalcium phosphate & 0.50 & 0.40 & 0.50 & 0.70 \\
Mineral for horses* & 0.20 & 0.20 & 0.20 & 0.20 \\
Vitamins for horses & 0.20 & 0.20 & 0.20 & 0.20 \\
\hline
\end{tabular}

*:*Guaranteed Analysis: Linoleic acid: $3.630 \mathrm{mg} / \mathrm{kg}$; Oleic Acid: $3 \mathrm{mg} / \mathrm{kg}$; Calcium (min.): $150 \mathrm{~g} / \mathrm{kg}$; Calcium (max.): $170 \mathrm{~g} / \mathrm{kg}$; Phosphorus: 80 g/kg; Sodium: 121 g/kg; Potassium: 10 g/kg; Sulfur: 4.954 mg $/ \mathrm{kg}$; Cobalt: 30 mg/kg; Tyrosine: $34 \mathrm{mg} / \mathrm{kg}$; Copper: 1.400 $\mathrm{mg} / \mathrm{kg}$; Iodine: $200 \mathrm{mg} / \mathrm{kg}$; Chrome: $12 \mathrm{mg} / \mathrm{kg}$; Lysine: $4.000 \mathrm{mg} / \mathrm{kg}$; Magnesium: $7.225 \mathrm{mg} / \mathrm{kg}$; Manganese: $1.400 \mathrm{mg} / \mathrm{kg}$; Phosphatidylcholine: $1.000 \mathrm{mg} / \mathrm{kg}$; Methionine: $14 \mathrm{mg} / \mathrm{kg}$; Selenium: $27 \mathrm{mg} / \mathrm{kg}$; Iron: $2.000 \mathrm{mg} / \mathrm{kg}$; Zinc: $3.500 \mathrm{mg} / \mathrm{kg}$; Vitamin A: $85.000 \mathrm{KIU} / \mathrm{kg}$; Vitamin C: $200 \mathrm{mg} / \mathrm{kg}$; Vitamin D: $8.500 \mathrm{KIU} / \mathrm{kg}$; Vitamin E: $200 \mathrm{mg} / \mathrm{kg}$; Saccharomyces cerevisiae: 0.01500x10 $\mathrm{CFU} / \mathrm{kg}$.

Table 2. Diet chemical composition with increasing inclusion levels of DMG

\begin{tabular}{lccccc}
\hline \multirow{2}{*}{ Nutrients* } & \multicolumn{2}{c}{ Concentrate nutrient composition on a DM basis $(\%)$} & Roughage \\
\cline { 2 - 6 } & 0 & 10 & 20 & 30 & Hay \\
\hline DM & 90.56 & 90.34 & 90.71 & 90.91 & 89.657 \\
OM & 91.38 & 90.91 & 91.01 & 90.86 & 94.18 \\
MM & 8.62 & 9.09 & 8.99 & 9.14 & 5.82 \\
CP & 15.38 & 15.33 & 14.22 & 15.4 & 6.51 \\
EE & 3.69 & 4.06 & 4.1 & 3.9 & 1.71 \\
NDF & 20.18 & 21.89 & 24.35 & 26.88 & 79.87 \\
ADF & 5.5 & 5.2 & 6.25 & 6.4 & 36.67 \\
HC & 15.25 & 16.69 & 18.62 & 20.49 & 43.2 \\
St & 38.27 & 37.97 & 35.95 & 34.72 & 6.65 \\
GE & 3865.50 & 3898.00 & 3915.00 & 3936.50 & 3925.00 \\
\hline
\end{tabular}

Diet nutrient composition on DM bases (forage: concentrate ratio - 50:50)

\begin{tabular}{lcccc}
\hline & 0 & 10 & 20 & 30 \\
\cline { 2 - 5 } DM & 90.11 & 90.00 & 90.18 & 90.28 \\
OM & 92.78 & 92.55 & 92.60 & 92.52 \\
MM & 7.22 & 7.46 & 7.41 & 7.48
\end{tabular}




\begin{tabular}{lcccc}
$\mathrm{CP}$ & 10.95 & 10.92 & 10.37 & 10.96 \\
$\mathrm{EE}$ & 2.70 & 2.89 & 2.91 & 2.81 \\
$\mathrm{NDF}$ & 50.03 & 50.88 & 52.11 & 53.38 \\
$\mathrm{ADF}$ & 21.09 & 20.94 & 21.46 & 21.54 \\
$\mathrm{HC}$ & 29.23 & 29.95 & 30.91 & 31.85 \\
$\mathrm{St}$ & 22.46 & 22.31 & 21.30 & 20.69 \\
$\mathrm{GE}(\mathrm{Kcal} / \mathrm{g})$ & 3895.25 & 3911.50 & 3920.00 & 3930.75 \\
\hline
\end{tabular}

*Dry matter (DM); Organic matter (OM); Mineral matter (MM); Crude Protein (CP); Ethereal extract (EE); Neutral detergent fiber (NDF); Acid detergent fiber (ADF); Hemicellulose (HC); Starch (St); and, Gross energy (GE) (Kcal/g).

The defatted maize germ used in this study has the following chemical composition: $95.86 \%$ Dry Matter (DM); $1.92 \%$ Organic matter (OM); 20.4\% Crude Protein (CP); 60.76\% Neutral detergent fiber (NDF); $11.54 \%$ Acid detergent fiber (FDA); 49.24\% Hemicellulose (HC); $10.18 \%$ Cellulose (CEL); $10.20 \%$ Ether extract (EE); and $16.78 \%$ Starch $(\mathrm{St})$.

The trial lasted 72 days, divided into four 15-day periods and four resting days between periods. It included a 10-day period of adaptation to the diet, four days of total feaces collection and one day of blood collection. The daily feces production was collected entirely during the sampling period, and at the end, the feces samples of each animal were pooled together. The final feces and diet samples were sent to the laboratory for chemical analysis. Analyses to determine dry matter (DM), mineral matter (MM), ether extract (EE), crude protein $(\mathrm{CP})$, were performed according to the method described by AOAC (1995). The acid (ADF) and neutral (NDF) detergent fiber analyses, and cellulose (CEL) were determined following the procedure described by Van Soest et al. (1991). The gross energy was determined using a bomb calorimeter. The starch was quantified using a colorimetric technique (HENDRIX, 1993).

The feces samples were used to determine the apparent digestibility coefficient (ADC), according to Andriguetto (1982) recommendations, and the following physicochemical parameters: consistency $(1=$ extremely hard, $3=$ normal; $5=$ diarrhea) (BERG et al., 2005); color (greenish (normal), black, reddish or yellowish) (GODOI et al., 2009). The $\mathrm{pH}$ was determined using a bench $\mathrm{pH}$ meter introduced directly into fresh feces; and, the buffering capacity (BC) at $\mathrm{pH} 5$ and 6 . A 50-g aliquot of each feces sample was added to $80 \mathrm{~mL}$ of distilled water, homogenized and filtered. Subsequently, an 80-mL aliquot of the obtained liquid was titrated with $0.25 \mathrm{M}$ acetic acid. Results were obtained according to the equation: $\mathrm{BC}$ $(\mathrm{mmol} / \mathrm{L})=$ Volume $(\mathrm{mL}) * 3.125$ (ZEYNER et al., 2004). To determine fecal short-chain fatty acids
(SCFA), an aliquot of $10 \mathrm{~g}$ of feaces was collected daily, mixed with $30 \mathrm{~mL}$ of $1 \mathrm{~N}$ formic acid $\left(\right.$ Merck $\left.^{\circledR}\right)$, then packed in $120-\mathrm{mL}$ plastic tubes, which were the frozen at $-20^{\circ} \mathrm{C}$ until further use. The SCFA concentrations were determined by gas chromatography.

For the analysis of blood glucose, insulin, serum lipid profile and (SCFA), the blood was collected from the jugular vein by venipuncture at times: immediately before feeding, and $1 \mathrm{~h} 00,3 \mathrm{~h} 00$ and $6 \mathrm{~h} 00$ hours after feeding. The blood was centrifuged, the serum/plasma stored in Eppendorf tubes and frozen. Biochemical kits for spectrophotometer readings were used to determine cholesterol, triglycerides (appoint in serum), and glucose (appoint in plasma). The SCFA concentrations were determined by gas chromatography according to the methodology described by Hussein et al. (2004), appoint in plasma. Insulin was determined using the Biochemical kit Roche diagnostic ${ }^{\circledR}$ for electrochemiluminescence technique, appoint in serum.

The results were analyzed using the statistical software, SAS for Windows (SAS, 2000). The digestibility results were analyzed using a linear mixed model, considering the inclusion levels as the fixed effect $(0,10,20$ and 30\%) and the animals within the Latin square (QL) as the random effect. In the case of significant effect for inclusion level, regression analysis was performed.

For the physicochemical characteristics of the feces, the means were compared by Tukey test at $5 \%$ significance level. The frequency of feaces consistency and color parameters was compared using the chi-square test. The blood parameters were compared using a linear mixed model, considering sampling time as the fixed effect and the animals within the Latin square (QL) as the random effect. In the case of significant effect for sampling times, regression analysis was performed. 


\section{RESULTS}

As expected, there was no effect $(\mathrm{P}>0.05)$ of inclusion levels of defatted maize germ on the apparent digestibility coefficient of diet nutrients (Table 3) since diet nutritional compositions were similar.

Table 3. Apparent digestibility coefficients of diets with increasing inclusion levels of DMG.

\begin{tabular}{lcccccc}
\hline \multirow{2}{*}{ Nutrients } & \multicolumn{4}{c}{ Inclusion levels of DMG $(\%)$} & \multirow{2}{*}{ CV (\%) } & \multirow{2}{*}{ p-value } \\
\cline { 2 - 5 } & 0 & 10 & 20 & 30 & & \\
\hline $\mathrm{DM}_{\mathrm{ADC}}$ & $48.9 \pm 4.0$ & $50.3 \pm 4.3$ & $49.6 \pm 1.7$ & $50.3 \pm 3.7$ & 6.50 & 0.7942 \\
$\mathrm{OM}_{\mathrm{ADC}}$ & $50.2 \pm 3.6$ & $51.6 \pm 4.2$ & $50.6 \pm 1.7$ & $51.4 \pm 3.8$ & 6.18 & 0.7595 \\
$\mathrm{CP}_{\mathrm{ADC}}$ & $58.1 \pm 4.9$ & $59.2 \pm 5.0$ & $57.4 \pm 2.6$ & $60.4 \pm 6.3$ & 7.70 & 0.6585 \\
$\mathrm{GE}_{\mathrm{ADC}}$ & $46.0 \pm 4.0$ & $45.9 \pm 4.6$ & $46.7 \pm 1.7$ & $49.0 \pm 5.6$ & 8.49 & 0.6962 \\
$\mathrm{EE}_{\mathrm{ADC}}$ & $43.7 \pm 7.5$ & $42.2 \pm 6.3$ & $40.9 \pm 7.8$ & $39.8 \pm 7.1$ & 15.88 & 0.8743 \\
$\mathrm{NDF}_{\mathrm{ADC}}$ & $36.3 \pm 3.4$ & $35.2 \pm 2.8$ & $35.5 \pm 1.2$ & $35.9 \pm 2.5$ & 6.58 & 0.8914 \\
$\mathrm{ADF}_{\mathrm{ADC}}$ & $25.7 \pm 1.8$ & $24.9 \pm 2.1$ & $25.9 \pm 2.0$ & $26.6 \pm 0.9$ & 6.55 & 0.6268 \\
$\mathrm{HC}_{\mathrm{ADC}}$ & $46.2 \pm 8.5$ & $43.7 \pm 4.6$ & $44.5 \pm 1.6$ & $45.2 \pm 4.19$ & 10.80 & 0.6035 \\
$\mathrm{St}_{\mathrm{ADC}}$ & $93.3 \pm 0.4$ & $94.2 \pm 0.6$ & $93.8 \pm 1.0$ & $93.4 \pm 1.5$ & 1.01 & 0.4814 \\
\hline
\end{tabular}

Dry matter apparent coefficients $\left(\mathrm{DM}_{\mathrm{ADC}}\right)$, organic matter apparent coefficients $\left(\mathrm{OM}_{\mathrm{ADC}}\right)$, crude protein apparent coefficients $\left(\mathrm{CP}_{\mathrm{ADC}}\right)$, gross energy apparent coefficients $\left(\mathrm{GE}_{\mathrm{ADC}}\right)$, ether extract apparent coefficients $\left(\mathrm{EE}_{\mathrm{ADC}}\right)$, neutral detergent fiber apparent coefficients $\left(\mathrm{NDF}_{\mathrm{ADC}}\right)$, acid detergent fiber apparent coefficients $\left(\mathrm{ADF}_{\mathrm{ADC}}\right)$, hemicellulose apparent coefficients $(\mathrm{HC} \mathrm{ADC})$, starch apparent coefficients $\left(\mathrm{St}_{\mathrm{ADC}}\right)$

The diet fiber content and starch digestibility maintained the physicochemical parameters of feaces (all animals produced normal consistency feces with greenish color) and blood, as shown by the constant levels of short-chain fatty acids (SCFA) (Table 4), both were not affected by the diets $(\mathrm{P}>0.05)$.
Horse feaces had high levels of acetate, an average $12.5 \mathrm{mmol}$ compared to the average propionate level of $4.4 \mathrm{mmol}$, but the parameters were not affected $(\mathrm{P}>0.05)$ by the diets. This result also corroborates the health status of the large intestine and the desired fermentation of the main substrate of the diet, the roughage, and high fiber concentrate.

Table 4. Effect of diets containing increasing levels of DMG on horse feces quality

\begin{tabular}{|c|c|c|c|c|c|c|}
\hline \multirow{2}{*}{ Parameters } & \multicolumn{4}{|c|}{ Inclusion levels (\%) } & \multirow{2}{*}{$\mathrm{CV}(\%)$} & \multirow[b]{2}{*}{$\mathrm{p}$-value } \\
\hline & 0 & 10 & 20 & 30 & & \\
\hline $\mathrm{pH}$ & $7.0 \pm 0.5$ & $6.7 \pm 0.7$ & $6.6 \pm 0.6$ & $6.6 \pm 0.5$ & 8.76 & 0.1832 \\
\hline BC6* & $7.4 \pm 1.5$ & $6.4 \pm 1.7$ & $7.1 \pm 3.0$ & $6.8 \pm 2.5$ & 32.50 & 0.5862 \\
\hline $\mathrm{BC} 5 * *$ & $22.5 \pm 3.3$ & $21.7 \pm 3.8$ & $22.6 \pm 4.0$ & $24.0 \pm 4.6$ & 17.33 & 0.6793 \\
\hline SCFA $* * *$ & $12.8 \pm 7.8$ & $13.2 \pm 8.0$ & $17.6 \pm 3.7$ & $15.7 \pm 6.2$ & 42.31 & 0.1605 \\
\hline
\end{tabular}

**Buffering capacity at pH $5(\mathrm{mmol} / \mathrm{L})$, *Buffering capacity pH 6 (mmol/L) short-chain fatty acids (SCFA) (mmol/L)

The SCFA levels in the blood behaved similarly to the levels of acetate compared to propionate. The total fatty acids levels were not affected by the diets $(\mathrm{P}>0.05)$ and remained constant. The same behavior was observed for blood cholesterol, glucose, and insulin (Table 5).

Table 5. Effect of diets with increasing levels of DMG on blood parameters means of horses

\begin{tabular}{lcccccc}
\hline \multirow{2}{*}{ Parameters } & \multicolumn{4}{c}{ Inclusion levels $(\%)$} & \multirow{2}{*}{ CV (\%) } & p-value \\
\cline { 2 - 5 } & 0 & 10 & 20 & 30 & & \\
\hline Cholesterol $(\mathrm{mg} / \mathrm{dL})$ & $97.1 \pm 9.2$ & $95.8 \pm 7.5$ & $96.6 \pm 6.1$ & $98.0 \pm 0.2$ & 8.55 & 0.1824 \\
Triglycerides $(\mathrm{mg} / \mathrm{dL})$ & $31.2 \pm 4.7$ & $32.9 \pm 6.5$ & $34.6 \pm 6.0$ & $39.2 \pm 4.8$ & 17.69 & $<0.0001$ \\
Glucose $(\mathrm{mg} / \mathrm{dL})$ & $86.5 \pm 8.8$ & $95.9 \pm 20.9$ & $90.8 \pm 13.6$ & $90.0 \pm 13.8$ & 16.49 & 0.1160 \\
Insulin $(\mu \mathrm{U} / \mathrm{ml})$ & $4.5 \pm 2.7$ & $4.6 \pm 3.3$ & $3.3 \pm 3.2$ & $3.9 \pm 2.7$ & 72.02 & 0.6289 \\
SCFA $(\mathrm{mmol} / \mathrm{L})$ & $1.5 \pm 0.3$ & $1.4 \pm 0.1$ & $1.5 \pm 0.3$ & $1.4 \pm 0.2$ & 15.59 & 0.6547 \\
\hline
\end{tabular}


The concentration of triglycerides was the only blood parameter affected by the diets (P> $0.05)$. The linear effect of diet on triglycerides was represented by the equation $\hat{y}=30.62+0.26 x$ (Table 5). This result was not expected, and can be explained by Cocate et al. (2008) who suggested that eating low glicemic index (GI) foods decreases the release of postprandial plasma insulin, promoting fat oxidation at the expense of carbohydrate, and increasing the availability of fatty acids.

The blood glucose and insulin levels were significantly $(\mathrm{P}<0.05)$ affected by the diets and time, while others were not affected $(\mathrm{P}>0.05)$ (Table 6). There was no interaction between diet and sampling time $(\mathrm{P}>0.05)$ for any of the parameters studied.

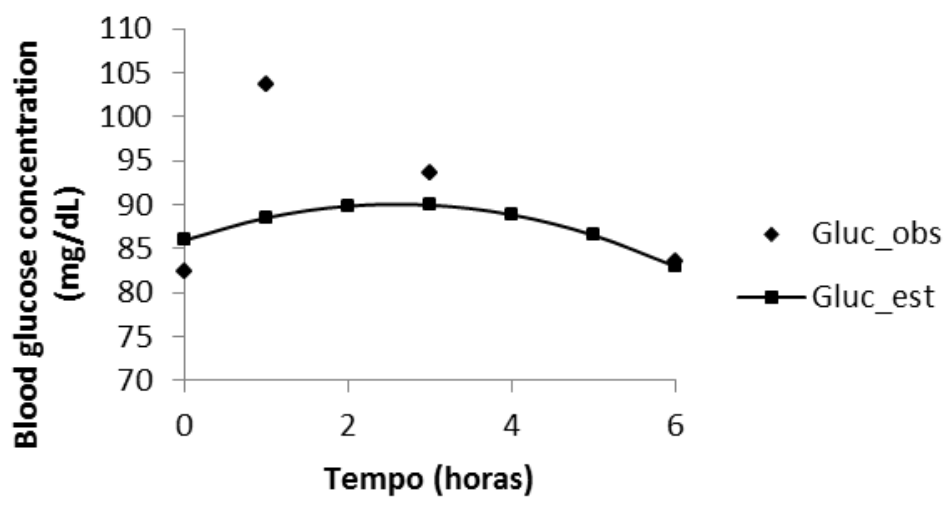

Figure 1. Effect of collection time on blood glucose concentration of equine fed diets with increasing inclusion levels of DMG

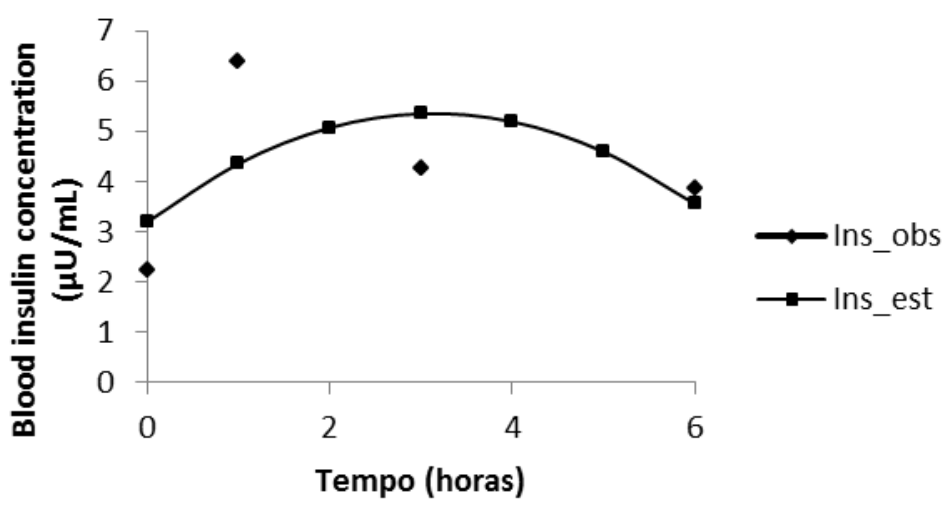

Figure 2. Effect of collection time on blood insulin concentration of equine fed diets with increasing inclusion levels of DMG

\section{DISCUSSION}

The apparent digestibility coefficients found for NDF, ADF, HC and GE are similar to those reported by Moreira et al. (2014) and Correa et al. (2016) for citrus pulp and corn gluten 21, respectively. According to Perali et al. (2001), DM digestibility is directly related to the fiber fraction because DM affects cell exposure to the animal organism, allowing its digestion and absorption in the gastrointestinal tract. Thus, the low NDF and ADF percentages in diet ingredients can lead to an increase of DM digestibility. The experimental diet had average NDF digestibility of $35.5 \%$, which can be considered low (Pagan, 1998). It is suggested that the observed digestibility values were affected by the quality of the hay used predominantly in this diet, with high percentages of NDF and ADF (Table 2 ). The quality of hay might have influenced the digestibility of the diet fibrous fraction.

The $\mathrm{CP}_{\mathrm{ADC}}$ was lower than that observed by Correa et al. (2016). This difference can be attributed to the hay quality, which had $6.51 \%$ crude protein, and the quality and amount of the protein that originated from defatted maize germ that even with $20.4 \%$ protein, did not display good digestibility coefficient. 
It is noteworthy that the high digestibility achieved for starch (93.7\%), can be attributed to the low inclusion level of this nutrient, about $288 \mathrm{~g}$ per meal, less than the $483 \mathrm{~g}$ (about $1.1 \mathrm{~g}$ of starch per $\mathrm{kg}$ of animal, per meal) recommended by Vervuert et al. (2009). The high digestibility coefficient observed seem to suggest that no excessive amount of starch passed through the large intestine, thus keeping the fermentation profile of the compartment, as stated by Zeyner et al. (2004).

The prevalence of roughage in the diet may also have influenced greatly the parameters examined in this study since the diet was composed of $68 \%$ natural matter from the bulky. The digestibility coefficients obtained in this study are similar to those obtained in similar studies using only bulky (FURTADO et al., 1999) and super fiber sources as food for horses (QUADROS et al., 2004, BRANDI et al., 2014; MOREIRA et al., 2014, CORREA et al., 2016).

The greenish color and normal consistency of horse feces is due mainly to the color of the roughage used in diet and indicate possibly the good health of the gastrointestinal tract (SANTOS et al., 2009). Also, the observed $\mathrm{pH} 6.7$ average is considered an optimal value for the fermentation in the large intestine, as reported by Van Soest (1994). The maintenance of the $\mathrm{BC}$ values at $\mathrm{pH} 5$ and $\mathrm{pH}$ 6 , corroborate the health status of the gastrointestinal tract since this parameter indicates the resistance capacity of the large intestine against $\mathrm{pH}$ variations. Santos et al. (2004) investigated a starch overload in diets for horses and reported higher values than those obtained in this study, thus suggesting that there was no starch overload in the large intestine.
Glycemic, insulinemic and cholesterolemic values near the baseline are desired and maybe a result from the fiber action that delayed gastric emptying with high inclusion of lower hay quality (high percentage of NDF and ADF), according to Capito and Filisetti (1999).

The highest glucose and insulin levels were achieved between 2-3 hours, and 3-4 hours after feeding, respectively, in agreement with Vervuert et al. (2004) and higher than the values reported by Correa et al. (2016) for corn gluten 21. It is suggested that this difference may be attributed to the high starch digestibility obtained in this study. As recommended by Staniar et al. (2007), the blood glucose curves close to the baseline values are beneficial to horse metabolism and can be favored by diets with high roughage and fiber contents. The prolonged period in which the blood glucose and insulin levels remained high can be considered a plus, as it contributes to constant energy supply to the horse between feedings, as reported by Demarco et al. (1999) and Thomas et al. (1991). These authors suggested that fiber ingestion resulted in slower and prolonged glycemic rise, favoring more constant blood glucose levels during the periods of horse maintenance or exercise.

\section{CONCLUSION}

The defatted maize germ can be included up to $30 \%$ of the concentrate (up to $9,6 \%$ of the diet) without changing the diet apparent digestibility coefficient, the feaces and blood physicochemical parameters. It can be used as an alternative ingredient for high fiber diets and can contribute to formulating diets with lower glycemic and insulinemic indexes.

RESUMO: O objetivo deste estudo foi estudar efeito dos níveis de inclusão de gérmen de milho desengordurado (GMD) através de ensaio de digestibilidade aparente, características físico-químicas das fezes e parâmetros sanguíneos. Foram utilizados quatro equinos adultos, com peso vivo de $483.3 \pm 27.5 \mathrm{~kg}$, dispostos em quadrado latino $4 \times 4$. As dietas consistiram de $50 \%$ da energia proveniente do volumoso (feno de Jiggs) e $50 \%$ provenientes do concentrado composto por níveis crescentes de inclusão de GMD (0, 10, 20 e 30\%). Para a determinação da digestibilidade, coleta total de fezes foi feita. As características de cor, consistência, $\mathrm{pH}$ e Capacidade Tamponante (CT) a 5 e a 6 das fezes, foram determinadas diariamente durante os dias de coleta. Para a determinação dos parâmetros sanguíneos, o sangue foi colhido por venopunção da jugular, com tubos a vácuo e a concentração de glicose, triglicérides, colesterol e insulina foram determinados com a utilização de kits bioquímicos e a concentração de ácidos graxos de cadeia curta por cromatografia gasosa. Não houve efeito das dietas sobre a digestibilidade dos nutrientes $(\mathrm{P}>0,05)$, $\mathrm{pH}$ fecal (média 6,7) e capacidade tamponante a pH $5(22,7)$ e pH 6, (6,9) e concentração de ácidos graxos de cadeia curta nas fezes. Não houve efeito das dietas $(\mathrm{P}>0,05)$ sobre as concentrações sanguíneas de glicose, insulina, colesterol, ácidos graxos de cadeia curta totais, porém houve efeito $(\mathrm{P}<0,05)$ das dietas sobre a concentração sanguínea de triglicérides, descrita pela equação $\hat{y}=30,62+0,26 x$. Houve efeito do tempo de coleta $(\mathrm{P}<0,05)$ sobre as variáveis triglicérides, glicose e insulina, descritas pelas respectivas equações: $\hat{y}=32,30+0,87 x, \hat{y}=85,93+3,17 x-0,61 x^{2}, \hat{y}=3,19+1,38 x-0,22 x^{2}$. O gérmen de milho desengordurado pode ser incluído até $30 \%$ do concentrado (até 9,6\% da dieta) sem alterar a digestibilidade das dietas, parâmetros físico-químicos das fezes e parâmetros sanguíneos. Este pode ser um ingrediente 
alternativo para dietas com alta fibra e pode contribuir para a formulação de dietas com menores índices glicêmicos e insulinêmicos.

PALAVRAS-CHAVE: Cavalos. Coproduto. Digestibilidade. Metabolismo. Nutrição.

\section{REFERENCES}

ANDRIGUETTO, J. M.; PERLY. L.; MINARDI, I.; GEMAEL, A.; FLEMMING, J. S.; SOUZA, G. A.; FILHO, A. B. Nutrição animal. Curitiba: Universidade Federal do Paraná, v.1, 395 p., 1982.

AOAC. Official methods of analysis. 16.ed. Association of Official Analytical Chemistry, Arlington, VA. 1995.

BERG, E. L.; FU, C. J.; POTTER, J. H.; KERLEY, M. S. Fructooligosaccharide supplementation in the yearling horse: effects on fecal $\mathrm{pH}$, microbial content, and volatile fatty acid concentrations. Journal of Animal Science, Champaign, v. 83, n. 7, p. 1549-1553. 2005. http://dx.doi.org/10.2527/2005.8371549x

BRANDI, R. A.; TRIBUCCI, A. M. O.; BALIEIRO, J. C. C.; HOFFMAN, R. M. Citrus Pulp in Concentrates for Horses. Food and Nutrition Sciences, Nova York, v. 5, p. 1272-1279. 2014.

BRUNELLI, S. R.; PINHEIRO, J. W.; SILVA, C. A.; FONSECA, N. A. N.; OLIVEIRA, D. D.; CUNHA, G. E.; SOUZA, L. F. A. Inclusão de farelo de gérmen de milho desengordurado na alimentação de frangos de corte, Revista Brasileira de Zootecnia, Viçosa, v. 35, n. 4, p. 1349-1358, 2006.

CAPITO, S. M. P.; FILISETI, T. M. C. C. Inulina: Um ingrediente alimentar promissor. Revista da Sociedade Brasileira e Nutrição. São Paulo, n. 18, p. 1-11, 1999.

COCATE, P. G.; ALFENAS, R. C. G.; PEREIRA, L. G. Índice glicêmico: resposta metabólica e fisiológica antes, durante e após o exercício físico. Revista Mackenzie de Educação Física e Esporte, São Paulo, v. 7, n. 2, p. 109-117, 2008.

CORREA, G. F.; NASCIMENTO, O. C. A. ; MOTA, T. P. ; HESPANHOLO, G. O. ; MOREIRA, C. G.; MENEZES, M. L. ; VERVUERT, I. ; BALIEIRO, J. C. C. ; BUENO, I. C. S. ; BRANDI, R. A. Impact on digestibility, and blood and fecal parameters of replacing wheat bran with corn gluten meal in concentrate of adult horses. Livestock Science, Amsterdam, v. 186, p. 41-45, 2016. doi:10.1016/j.livsci.2015.06.001.

COVERDALE, J. A.; MOORE, J. A.; TYLER, H. D.; MILLER-AUWERDA, P. A. Soybean hulls as an alternative feed for horses. Journal of Animal Science, Champaign, v. 82, p. 1663-1668. 2004. http://dx.doi.org/10.2527/2004.8261663x

DEMARCO, H. M.; SUCHER, K. P.; CISAR, C. J.; BUTTERFIELD, G. E. Pre-exercise carbohydrate meals: application of glycemic index. Medicine \& Science in Sports Exercise, Indianapólis, v. 31, p. 164 - 170, 1999. http://dx.doi.org/10.1097/00005768-199901000-00025

DUREN, S. Feeding the endurance horse, Kentucky equine Research, Inc. 2000. 351-363 p.

FRAPE, D. Nutrição \& alimentação de equinos. 3.ed. São Paulo: Roca, 602 p. 2008.

FURTADO, C. E.; BRANDI, R. A.; RIBEIRO, L. B. Utilização de coprodutos e demais alimentos alternativos para dietas de equinos. Revista Brasileira de Zootecnia, Viçosa, v.40, p.214-223, 2011.

FURTADO, C. F.; CABRERA, L.; FONSECA, N. A. N.; PINHEIRO, J. W.; ARAGÃO, D. A.; BELINELLI, E.; OLIVEIRA, C. A. A. Avaliação da digestibilidade aparente de fenos de gramíneas e de leguminosa para equinos. Acta Scientiarum, Maringá, v. 21, p. 651-655. 1999. 
GODOI, F. N.; ALMEIDA, F. Q.; GUARIENTI, G. A.; SANTIAGO, J. M.; JÚNIOR, D. G.; NOGUEIRA, Y. C. Perfil hematológico e características das fezes de equinos consumindo dietas hiperlipidêmicas. Ciência Rural, Santa Maria, v. 39, p. 2571-2577. 2009. http://dx.doi.org/10.1590/S0103-84782009000900029

HENDRIX, D. L. Rapid extraction and analysis of non-structural carbohydrates in plant tissues. Crop Science, Madison, v. 33, p. 1306-1311. 1993. http://dx.doi.org/10.2135/cropsci1993.0011183X003300060037x

HUSSEIN, H. S.; VOGEDES, L. A.; FERNANDEZ, G. C. J.; FRANKENY, R. L. Effects of cereal grain supplementation on apparent digestibility of nutrients and concentrations of fermentation end-products in the feaces and serum of horses consuming alfalfa cubes. Journal of Animal Science, Champaign, v. 82, p. 19861996. 2004. http://dx.doi.org/10.2527/2004.8271986x

MANZANO, A.; FREITAS, A. R.; ESTEVES, S. N.; NOVAES, N. J. Polpa de citros peletizada na alimentação de equinos. Revista Brasileira de Zootecnia, Viçosa, v. 29, n. 6, p. 1327-1332. 1999.

MENEZES, M. L.; BRANDI, R. A.; BUENO, I. C. S.; BALIEIRO, J. C. C.; MOREIRA, C. G.; NASCIMENTO, O. C. A. Efeitos de dietas com níveis crescentes de polpa cítrica sobre os parâmetros sanguíneos ligados ao metabolismo energético em equinos. Ciência e Agrotecnologia [online], Lavras, v. 38, n. 6, p. 589-597. 2014.

MOREIRA, C. G.; BRANDI, R. A.; BUENO, I. C. S.; MENEZES, M. L.; MOTA, T. P.; SOUZA, A. D.; TAVARES, A. F.; AUGUSTO, L. S. Palatability and digestibility of horse diets containing increasing levels of citrus pulp. MVZ Córdoba, Córdoba, v. 20, p. 4546-4557, 2015.

MOREIRA, I.; RIBEIRO, C. R.; FURLAN, A. C.; SCAPINELLO, C.; KUTSCHENKO, M. Utilização do Farelo de germe de milho desengordurado na alimentação de suínos em crescimento e terminação digestibilidade e desempenho. Revista Brasileira de Zootecnia, Viçosa, v. 31, n. 6, p. 2238-2246, 2002.

NRC. Nutrient Requirements of Horses. sixth ed. The National Academies Press, Washington. 2007.

PAGAN, J. D. 1998. Advances in equine nutrition. Kentucky, USA: Kentucky Equine Research, p. 57-70, 1998.

PERALI, C.; FREITAS L. J. A.; FIALHO, E. T.; BETERCCHINI, A. G.; ARAÚJO, K. V. Valores nutricionais de alimentos para equinos. Ciência e Agrotecnologia, Lavras, v. 25, n. 5, p. 1216-1224, 2001.

PEZZATO, L. E.; MIRANDA, E. C.; BARROS, M. M.; PINTO, L. G. Q.; FURUYA, W. M.; PEZZATO, A. C. Digestibilidade Aparente de Ingredientes pela Tilápia do Nilo (Oreochromis niloticus). Revista Brasileira de Zootecnia, Viçosa, v. 31, n. 4, p. 1595-1604, 2002.

QUADROS, J. B. S.; FURTADO, C. E.; BARBOSA, E. D.; ANDRADE, M. B.; TREVISAN, A. G. Digestibilidade Aparente e Desenvolvimento de Equinos em Crescimento Submetidos a Dietas Compostas por Diferentes Níveis de Substituição doFeno de Tifton 85 pela Casca de Soja. Revista Brasileira de Zootecnia, Viçosa, v. 33, n. 3, p. 564-574, 2004.

SANTOS, T. M.; ALMEIDA, F. Q.; GODOI, F. N. 2009. Capacidade tamponante, pH e consistência das fezes em equinos submetidos à sobrecarga dietética com amido. Ciência Rural, Santa Maria, v. 39, n. 6, p. 17821788. http://dx.doi.org/10.1590/S0103-84782009005000123

SANTOS, F. A. P.; PEREIRA, E. M.; PEDROSO, A. M. Suplementação energética de bovinos de corte em confinamento. In: SIMPÓSIO SOBRE BOVINOCULTURA DE CORTE, 5., Piracicaba, 2004. Anais... Piracicaba: FEALQ, 2004. p. 261-297

SAS INSTITUTE. The SAS system for windows. Release 8.01. Cary. 2000. 
STANIAR, W. B.; CUBITTA T. A.; GEORGE, L. A.; HARRIS, P. A.; GEOR, R. J. Glucose and insulin responses to different dietary energy sources in Thoroughbred broodmares grazing cool season pasture. Livestock Science, Amsterdam, v. 111, p. 164-171, 2007. http://dx.doi.org/10.1016/j.livsci.2007.01.148

THOMAS, D.; BROTHERHOOD, J.; BRAND, J. C. Carbohidrate feeding before exercise: effect of the glicemic index. Internacional Journal of Sports Medicine, Berlim, v. 12, p. 180 -186, 1991.

VAN SOEST, P. J.; ROBERTSON, J. P.; LEWIS, B. A. Methods for dietary fiber, neutral detergent fiber, and nonstarch polysaccharides in relation to animal nutrition. Journal of Dairy Science, Champaign, v. 74, p. 3583-3597. 1991. http://dx.doi.org/10.3168/jds.S0022-0302(91)78551-2

VAN SOEST, P. J. Nutritional ecology of the ruminant, Second ed. Cornell University Press, Ithaca. 1994.

VERVUERT, I.; COENEN, M.; BOTHE, C. Effects of corn processing on the glycaemic and insulinaemic responses in horses. Journal of Animal Physiology and Animal Nutrition, Berlim, v. 88, p. 348-355, 2004. http://dx.doi.org/10.1111/j.1439-0396.2004.00491.x

VERVUERT, I.; VOIGT, K.; HOLLANDS, T.; CUDDEFORD, D.; COENEN, M. Effect of feeding increasing quantities of starch on glycaemic and insulinaemic responses in healthy horses. Veterinary Journal, Amsterdam, v. 182, p. 67-72. 2009. http://dx.doi.org/10.1016/j.tvj1.2008.04.011

ZEYNER, A.; GEIBLER, C.; DITTRICH, A. Effects of hay intake and feeding sequence on variables in faeces and faecal water (dry matter, $\mathrm{pH}$ value, organic acids, ammonia, buffering capacity) of horses. Journal of Animal Physiology and Animal Nutrition, Berlim, v. 88, n. 1, p. 7-19. 2004. http://dx.doi.org/10.1111/j.14390396.2004.00447.x 